\title{
PROTECTING A WIFE FINANCIALLY AT THE TIME OF DIVORCE - A COMPARISON BETWEEN SOUTH AFRICAN WOMEN MARRIED IN TERMS OF SOUTH AFRICAN CIVIL LAW AND ISLAMIC LAW, WITH SPECIFIC REFERENCE TO THE $M A H R^{\star}$
}

\author{
Marita Carnelley
}

BA LLB LLM PhD

Professor of Law

University of Kwa-Zulu Natal, Pietermaritzburg

Suhayfa Bhamjee

\section{LLB LLM}

Senior Lecturer

University of Kwa-Zulu Natal, Pietermaritzburg

\section{SUMMARY}

This article compares the South African civil-law and Islamic-law positions with regard to the financial protective measures available to a wife at the time of marriage and divorce. In this regard, the respective matrimonial property systems are discussed, with special emphasis on civil antenuptial and Muslim marriage contracts. In addition, other protective measures inherent to the two systems to prevent prejudice both during the marriage and at the time of divorce, are discussed. It is submitted that, although the provisions of Islamic law do not provide the same financial protection for wives compared to the South African civil law, the Islamic concept of mahr could potentially be used in the Muslim marriage contract to enhance financial security of a Muslim wife at the time of divorce. The article also considers dual marriages where the same spouses marry each other in terms of both civil and Islamic law. In particular, the incorporation of the Islamic concept of mahr into civil antenuptial contracts is discussed with reference to the legal position in Canada to illustrate potential legal problems.

1

\section{INTRODUCTION}

Women in South Africa are - theoretically at least - able to make decisions about their financial independence, both before and during their marriage. 
These decisions will impact directly on their financial consequences at the time of a divorce. In some instances this freedom to negotiate and decide is regarded to be a fallacy - with subtle peer and parental pressures to get married (with or without guardian guidance), especially when the proverbial "biological clock" is ticking. This is especially the case in cultures where patriarchy remains prevalent. ${ }^{1}$

The biological reality is that nature often interferes with the career of a married woman, and the role of being a mother may impact on her professional decisions, and thus by implication also on her later financial independence. It could rightly be argued that this is not inevitable, as there are many women who successfully continue their careers whilst raising children. But for some mothers, the task of rearing children is placed above pursuance of a full-time career (or a less demanding career is accepted), with the belief that this is in the best interests of the family. This decision is mostly made with the consensus of the husband. The husband either directly, or by implication, undertakes or creates the impression that he will look after his wife financially in future. This dilemma has been noted by the court in Buttner v Buttner:

"Her relatively modest earning capacity is largely the result of the fact that, for some 27 years, she devoted her life to running the parties' home and raising their children, with the full agreement of the appellant."

As previously mentioned, the financial and career decisions made before and during a marriage, often have direct consequences at the time of a divorce of the parties. Experience has highlighted the engendered nature of divorce and the concomitant inequalities faced by women and men. The Constitutional Court in Bannatyne v Bannatyne noted that:

"[On] the breakdown of a marriage or similar relationship it is almost always mothers who become the custodial parent and have to care for the children. This places an additional financial burden on them and inhibits their ability to obtain remunerative employment. Divorced or separated mothers accordingly face the double disadvantage of being overburdened in terms of responsibilities and under-resourced in terms of means. Fathers, on the other hand, remain actively employed and generally become economically enriched.

These disparities undermine the achievement of gender equality which is a founding value of the Constitution."

To safeguard their financial position at the time of divorce, and to avoid this gender trap, it is important that women make the correct long-term financial decisions, before and during their marriage.

This article seeks to briefly set out the South African civil-law position with regard to the available financial protective measures available to a wife at the time of marriage and divorce. This will be compared to the equivalent Islamic-law provisions. In this regard, the matrimonial property systems are discussed, with special emphasis on civil antenuptial / Muslim-marriage

* With thanks to Munirah Osman-Hyder for her valuable comments on an earlier draft.

In Ryland v Edros 1997 (2) SA 690 (C) 717f-g, an expert witness noted that patriarchy is still prevalent in the Muslim community.

2 Buttner v Buttner 2006 (3) SA 23 (SCA) par 34.

3 Bannatyne v Bannatyne 2003 (2) BCLR 111 (CC) par 29-30. 
contracts. In addition, other protective measures inherent to the systems, to prevent prejudice both during the marriage and at the time of divorce, are also noted.

It is submitted that although the provisions of Islamic law do not provide the same financial protection for women compared to the South African law, the Islamic concept of mahr could potentially be used in the pre-marriage contract as a financial protective measure for the wife at the time of divorce. The use of mahr in a Western context is not uncommon, and the legal position in Canada is used to illustrate problems that could be experienced in this instance, where this Islamic principle is included in civil-marriage documents. ${ }^{4}$

\section{SOUTH AFRICAN CIVIL LAW}

A civil-law wife could protect herself financially in a number of ways to ensure that she is cared for at the time of divorce, by making certain choices at the time of entering into a marriage:

\section{Protection before and during the marriage}

The choice of matrimonial property system and the contents of the antenuptial contract are of particular importance in the arrangement of the financial aspects of a marriage, both during and after the marriage.

\section{Matrimonial property system}

The choice of the matrimonial property system applicable to the marriage, is the most important protective measure available to any spouse. This choice is generally made before the marriage is concluded, ${ }^{5}$ and determines the rights of the spouses to deal with any assets, and their ability to conclude joint debts during the marriage. The matrimonial property system also determines the legal protection available to one spouse, where the other's actions are financially prejudicial, as well as the division of the assets and liabilities at the time of divorce. There are three basic choices.

First, where the parties are married in community of property, the joint estate of the spouses is generally shared equally, subject to limited exceptions. ${ }^{6}$ During the marriage, the parties have equal powers in the

4 The possible constitutional issue of equality between wives married in terms of Islamic law and those married in terms of civil law, is ignored for the purposes of this paper. See in this regard, Denson "Non-recognition of Muslim Marriages: Discrimination and Social Injustice" 20092 Obiter 243-285; and Manjoo "The Recognition of Muslim Personal Laws in South Africa: Implementation for Women's Human Rights" July 2007 Human Rights Programme at Harvard Law School Working Paper 15-16 http://www.law.harvard.edu/programs/hrp/ documents/Manjoo_RashidaWP.pdf (accessed 2012-06-12).

5 Since 1984, it is possible to change the matrimonial property system during the marriage, through a court application by both parties jointly (Matrimonial Property Act 88 of 1984, s 21(1)).

6 Hahlo The South African Law of Husband and Wife (1985) 164-169. Some assets are regarded as the separate property of one of the spouses for purposes of inter partes spousal division - eg, assets received from a third-party estate/donor, where they were excluded 
managing of the joint estate, and for most important financial transactions the consent of both spouses is required. ${ }^{7}$ If one of the spouses enters into a transaction to the prejudice of the other spouse, often when the marriage is in the process of breaking down, there are statutory- and common-law protection measures available to the innocent spouse. These include a statutory right to adjustment at the time of divorce; ${ }^{8}$ dispensing with consent and suspension of the other spouse's powers vis-à-vis the joint estate ${ }^{9}$ and the possibility of immediate division of the joint estate. ${ }^{10}$ In instances of fraud, in terms of the common law, the innocent spouse has a right of recourse at time of divorce, an interdict to prevent a transaction, or the actio Pauliana utilis to reclaim the assets. ${ }^{11}$ These protection measures are unfortunately not infallible. ${ }^{12}$ Most of the statutory measures are dependent on spouses litigating against each other, and with the common-law measures evidence of fraud is a requirement - and this may be difficult to prove. $^{13}$

Second, where the parties are married out of community of property, with the inclusion of the accrual system, the two estates of the parties are separate, and each spouse has the independent power to manage his or her own estate. ${ }^{14}$ During the marriage, the parties are not liable for each other's debts, subject to the exception that the one spouse can bind the other financially for household necessaries. ${ }^{15}$ Again, where a spouse enters into a transaction to the prejudice of the possible accrual share of the other spouse, there are statutory- and common-law protection measures available to the innocent spouse, including the possible immediate division of the accrual: $;^{16}$ and the common-law possibilities of an interdict and the actio Pauliana utilis. The protection provided hereby is also not necessarily sufficient. ${ }^{17}$

Third, where the parties are married out of community of property and community of profit and loss without the accrual system, the estates of the

from the joint estate by the will or donation (Heaton The South African Family Law 3ed (2010) 168 96)

7 Matrimonial Property Act 88 of 1984 s 14 . S 15 differentiates between the type of consent required for various types of contracts. For example, informal consent is required to receive money due to the other spouse (s 15(3)(b)), but prior written and attested consent is required for a contract of surety for the debts of a third party (s 15(2)). See in general Hahlo The South African Law of Husband and Wife Chapter 14

8 Matrimonial Property Act s 15(9)(b).

9 Matrimonial Property Act s 16(1)-(2).

10 Matrimonial Property Act s 20.

11 Heaton The South African Family Law 82-83. The common-law measures can only be used in instances of fraud.

12 The statutory measures are dependent on a court application and the common-law measures are dependent on proof of fraud, specifically the intention to prejudice the innocent spouse. Imprudent prejudicial financial transactions do not fall within this category (Heaton The South African Family Law 82).

13 Heaton The South African Family Law 83.

14 Matrimonial Property Act 88 of 1984 s 3; Skelton and Carnelley Family Law in South Africa (2010) 108-115; and Heaton The South African Family Law 94-99.

15 This aspect is excluded from this discussion.

16 Matrimonial Property Act 88 of 1984 s 8(1).

17 Where the estate of the spouse has already depleted, there is no recourse for the prejudiced spouse (Heaton The South African Family Law 99-100). 
parties remain totally separate during the marriage, and each spouse has the independent power to manage his/her own estate, subject to the household-necessities exception. The parties are not liable for each other's debts during the marriage. As the estates are separate during and after the marriage, and as there is no legitimate expectation to share, no protective measures are provided for in the legislation. However, if this matrimonial property system is chosen, for whatever reason, the wife will have no protection during or after the marriage, as there is no right to share in the assets - especially since 1984/1988. ${ }^{18}$ Women married in terms of this system are particularly vulnerable if they chose to suspend their earning capacity to care for the family.

\section{Antenuptial contract (ANC)}

An antenuptial contract is generally entered into where the parties do not wish to be married in community of property. ${ }^{19}$ Apart from setting out the choice of matrimonial property system, the antenuptial contract ${ }^{20}$ can also make provision for the financial independence of the wife at the time of a divorce through inter partes pledges of benefits and donations, ${ }^{21}$ or by adding provisions dealing with succession (a provision what she will inherit upon the death of her husband) and the liability for household expenses. ${ }^{22}$ Although the succession clause can be amended only by a joint will by both spouses, ${ }^{23}$ a donation may be subject to conditions, including a condition that the donation is dependent on an uncertain future event such as the birth of a child, or that it would revert back to the donor at the time of a divorce. ${ }^{24}$ In these instances, the wife may not have the financial security at the time of divorce that seemed likely at the time of the marriage when the antenuptial contract was entered into.

It should be reiterated, however, that the antenuptial contract remains especially important in instances where the matrimonial property system does not make provisions for automatic sharing of assets at the time of divorce - specifically where the marriage is out of community of property without the accrual system after 1984/1988. The number of marriages falling into this category is less than the other two systems, as this is not a default

18 See discussion hereunder on the redistribution order.

19 Where the spouses do not enter into an antenuptial contract, the default system is that they are married in community of property (see Edelstein $v$ Edelstein 1952 (3) SA 1 (A)).

20 Donations between the spouses are valid and enforceable and need no longer be included in the antenuptial contract to be valid (Heaton The South African Family Law 61; and Skelton and Carnelley Family Law in South Africa 68-69 and 90).

21 Donations may be excluded inter partes from the joint assets (where married in community of property) or the division of the accrual (where married out of community of property with the retention of the accrual system) (Matrimonial Property Act S 5; Skelton and Carnelley Family Law in South Africa 82 111; and Heaton The South African Family Law 68). Donations made to a specific spouse by a third party, are excluded from this discussion.

22 Skelton and Carnelley Family Law in South Africa 105; and Heaton The South African Family Law 89.

23 Hahlo The South African Law of Husband and Wife 278. This agreement on how the estate of one or more parties will be divided after death, a pactun successorium, is generally unenforceable subject to the exception where spouses make such an agreement in their antenuptial contract (Skelton and Carnelley Family Law in South Africa 106).

24 Cumming v Cumming 1984 (4) SA 585 (T). 
choice. The spouses must specifically choose this non-sharing system, should they wish it to be applicable.

\section{Duty of spousal support}

One of the invariable consequences of a marriage is that there is a reciprocal duty between spouses to maintain each other during the marriage. ${ }^{25}$ This right is only available to a spouse during the existence of the marriage, and falls away when the marriage ends. Spousal maintenance after the divorce is only possible in terms of an agreement or a court order, at the time of the divorce. ${ }^{26}$

\section{Protection by the courts at time of divorce}

In the South African legal system, either spouse may institute a divorce - as long as it can be proved that there are legal grounds for the divorce. ${ }^{27}$

At the time of the divorce, if there is no agreement between the spouses, ${ }^{28}$ the matrimonial property system and the antenuptial contract are the starting points in determining the division of the estate(s). Where the parties are married in community of property, after payment of the joint debts the joint estate is divided equally between the spouses. ${ }^{29}$ Where the parties are married out of community of property with the inclusion of the accrual system, the parties share equally in the profits made (by either of the spouses) during the existence of the marriage. ${ }^{30}$ Where the parties are married out of community of property and community of profit and loss without the accrual system, there is no sharing at the time of divorce, ${ }^{31}$ unless provision is made therefore in the antenuptial contract or a court order. To reiterate, it is in this scenario where a wife, who compromised her career and earning capacity during the marriage for the benefit of the family, is often financially unprotected.

In addition hereto, the courts also have three discretionary options to award one spouse more or less than what would have been liable in terms of the matrimonial property system. From the outset, it must be noted that these three possibilities are only available if the relevant requirements are met, and cannot be used as a general tool to amend the rules of the matrimonial property to what the court may decide is fair and equitable.

25 Hahlo The South African Law of Husband and Wife 134. The law contains specific provisions with regard to household necessities, the payment of which is an exception to the usual matrimonial property-system rules, as spouses can bind each other for these necessities (Heaton The South African Family Law 48-51). A full discussion of this is outside the scope of this paper.

26 Divorce Act 70 of 1979 s 7(1)-(2). See discussion below.

27 Most divorces are grounded in the fact that the marriage is irretrievably broken done and that there are no reasonable prospects of reconciliation (Divorce Act 70 of $1979 \mathrm{~s} \mathrm{4,} \mathrm{subject} \mathrm{to} \mathrm{s}$ 5 (incurable mental illness or continuous unconsciousness)).

28 Heaton The South African Family Law 123-124.

29 See in general Hahlo The South African Law of Husband and Wife 382; Skelton and Carnelley Family Law in South Africa 152; and Heaton The South African Family Law 125.

30 Matrimonial Property Act 88 of 1984 s 3; Skelton and Carnelley Family Law in South Africa 108-115; and Heaton The South African Family Law 94-99.

31 Heaton The South African Family Law 92. 
The first possibility is a redistribution order where the parties were married out of community of property without the accrual system before $1984 / 1988 .^{32}$ The possibility of a redistribution order was included into the Matrimonial Property Act to assist women married out of community of property before the accrual system was introduced into legislation, meaning that those women could not share in the estate of the husband at the time of divorce. ${ }^{33}$ This is, however, not available to persons married after 1984/1988, where the spouses marry out of community of property without the accrual system. ${ }^{34}$ Where the courts have granted a redistribution order, the wives have been awarded between a third and a half of the estate of the husband. ${ }^{35}$

The second possibility is that the court can depart from the usual rules of the matrimonial property system, in terms of a forfeiture of benefit order. It is possible for the court to order a partial or total forfeiture of patrimonial benefits in instances where one of the spouses would unduly benefit from the marriage. ${ }^{36} \mathrm{~A}$ party cannot forfeit his/her own assets - only benefits he/she would have obtained from the marriage that he/she would not otherwise have had. ${ }^{37}$ The court does not have an unfettered discretion, but must take into account the following factors: the duration of the marriage, the reasons for the breakdown of the marriage, and any material misconduct by the parties. ${ }^{38}$ Forfeiture would thus not assist a wife where the husband is the main financial partner in the marriage.

The last option is a maintenance agreement or maintenance order at the time of the divorce, depending on the circumstances. Although the reciprocal duty of support ends at the time of the divorce, the Divorce Act makes provision for the duty to continue after the divorce, where the parties agree thereto, or where the court deems it appropriate. ${ }^{39}$ If there is no agreement, the court may only award maintenance in light of the listed factors in section $7(2)$, bearing in mind that there is a move away from permanent maintenance, and a long-term maintenance order for a younger wife or an economically active wife is unlikely. ${ }^{40}$

To conclude then, the courts do not have a general discretion to make a financial order that they deem as fair and equitable at the time of the divorce. They are largely bound to the rules of the matrimonial property system -

32 This provision applied to white, coloured and Asian persons. The provisions were made applicable to black persons in 1988 , by the Marriage and Matrimonial Property Law Amendment Act 3 of 1988.

33 Divorce Act s 7(3); Skelton and Carnelley Family Law in South Africa 159-164; and Heaton The South African Family Law 132-143.

34 For an example of this factual scenario, see Martin $v$ Martin unreported case number 2011/12734 (SGJ) dated 2011-11-23.

35 Beaumont v Beaumont 1987 (1) SA 967 (A); Bezuidenhout v Bezuidenhout 2005 (1) SA 580 (SCA); and Buttner v Buttner supra.

36 Divorce Act s 9.

37 Rousalis v Rousalis 1980 (3) SA 446 (C).

38 Divorce Act s 9; Singh v Singh 1983 (1) SA 781 (C); Skelton and Carnelley Family Law in South Africa 155-158; and Heaton The South African Family Law 130-132.

39 Divorce Act s 7(1) and s 7(2) respectively.

40 See in general Skelton and Carnelley Family Law in South Africa 132-141. 
subject to the three possibilities mentioned - unless the parties agree otherwise.

\section{Enforcement of agreements and court orders}

Fundamental to the South African legal system, is the principle that the court with the required jurisdiction ${ }^{41}$ would enforce any agreement or court order should one of the spouses not comply. ${ }^{42}$ The court will enforce the provisions of the matrimonial property system, as read with the antenuptial contract and other financial agreements. The court will accept the terms of the agreement, even where the parties were unequal in their bargaining power at the time of conclusion, in the absence of evidence of fraud or duress, unless the agreement is regarded as contra bonos mores. ${ }^{43}$

\section{Conclusion}

From the above discussion, it is clear that a wife married in terms of civil law can protect herself financially, either through her choice of matrimonial property system, and/or an antenuptial contract, or by the courts in certain limited instances at the time of divorce. The effects of a prima facie unfair antenuptial contract, can thus sometimes be ameliorated by a forfeiture of benefits order, a redistribution order, and/or an order for maintenance (if and where appropriate). All these options are enforceable in the courts.

However, the protection mechanisms are not all-encompassing. A spouse married out of community of property without the accrual system after $1984 / 1988$, remains especially vulnerable - mainly because there is not an automatic sharing of the assets at the time of the divorce.

\section{ISLAMIC LAW $^{44}$}

"In (Muslim minority) societies, where women are extremely vulnerable and often wronged, an appropriate marriage contract would assist in preventing injustices and preserving the marriage bond."

41 Divorce Act s 2(1).

42 The enforcement of any right can occur at the time of the violation of the right. Where the husband fails to maintain the spouse or act in a prejudicial manner as mentioned above, the enforcement may take place during the marriage.

43 The maintenance duty is also enforceable during the marriage (Maintenance Act 99 of 1998 s 2(1)).

44 It should be noted that approximately $1.5 \%$ of the 45 million persons in the South Africa 2001 census, profess to belong to the Islamic faith (Statistics South Africa Census 2001 Primary Tables South Africa. Census '96 and 2001 Compared (2004) 24 <http://www.statssa.gov.za /census01/html /RSAPrimary.pdf> (accessed 2011-10-13).

45 Omar Islamic Law of Divorce (2007) 27; Muslim Marriages Bill, $2010 \mathrm{~s}$ 8(1)(a); and Legal Resources Centre Submission to the Department of Justice: The Muslim Marriages Bill, 201014. 


\section{Protection before and during the marriage}

\section{Matrimonial property system}

For an Islamic woman living in South Africa and who is married only in terms of Islamic law, the situation is different from that of a woman married in terms of civil law. With an Islamic marriage (nikah) there is little choice with regard to the matrimonial property system unless it is addressed in the Muslimmarriage contract. Generally the estates of the spouses remain separate, similar to a civil marriage out of community of property and community of profit and loss without the accrual system. ${ }^{46}$ As mentioned above, wives married in terms of such a type of matrimonial property system are especially vulnerable. ${ }^{47}$

A marriage in community of property or a marriage out of community of property with the inclusion of the accrual system, in the traditional South African civil-law format, is generally regarded not to be Shariah-compliant, and not a viable option for the religious. ${ }^{48}$ The Association of Accountants and Lawyers for Islamic Law, however, argue that an amendment to the South African civil-law matrimonial property system, that includes the accrual system, could be made Shariah-compliant. ${ }^{49}$ In this regard, they suggest specifically that a clause is included in the antenuptial contract with the following provisions: one, that the value of the unpaid mahr must be stipulated in a money amount and not in weight of gold or silver and that this amount may be increased at the time of payment to keep up with inflation; two, that the husband gives his wife ownership of all the household movables or a part thereof or to any of his property; or three, that the husband gives his wife a percentage share in the annual profits in his business which she helps him run, or even without any reason.

Leaving aside the issue of the possibility of an accrual-type system, Muslim spouses in general retain the power over their own estates, and as there is no expectation of sharing in the other's estate apart from what is contained in the Muslim Marriage contract and the mahr, there are no other financial protective measures.

\section{Muslim marriage contract}

\section{General}

Muslim fiancées can enter into a Muslim marriage contract prior to the marriage (or during the marriage), to include provisions to protect the wife financially at the time of divorce.

46 Vahed Islãmic Family Law (2006) 19.

47 Bulbulia Discussion Paper: Proprietary Consequences of Muslim Marriages and Contractual Capacity of Spouses (2011) 3.

48 Association of Accountants and Lawyers for Islamic Law AMAL Newsletter (November 1986) 3. See also Bulbulia Discussion Paper 3.

49 November 1986 AMAL Newsletter 3.

50 See discussion above. 
Islamic marriage contracts are practical tools that allow couples to engage in negotiations to ensure their major goals and philosophies are in alignment. As far as the contract itself is concerned, the couple are at liberty to make the agreement as detailed as they wish. ${ }^{51}$ They may include terms concerning their place of abode or decisions regarding careers and children. ${ }^{52}$ The main method to secure some financial independence, is to include a donation to the wife in the form of a dower (mahr), or through a succession provision should the husband die before the wife..$^{53}$ Parties could also include a provision for the payment of maintenance beyond the usual three-month iddah period at the time of divorce, in their Muslim marriage contract. $^{54}$

\section{Mahr}

The issue of the mahr requires further clarification, as there are specific rules applicable thereto, whether or not it is included in the Muslim marriage contract or not. The mahr in Islamic law, also called a dower or nuptial gift, is "a sum of money or other property which the wife is entitled to receive from her husband in consideration of marriage". ${ }^{55}$ The mahr is neither a bride price, ${ }^{56}$ nor a dowry. ${ }^{57}$

The mahr is payable by all husbands to their wives married in terms of Islamic law. ${ }^{58}$ The payment of a mahr is obligatory, although the marriage is valid even if the mahr is not mentioned or determined. ${ }^{59}$ Mansoori states that there is agreement amongst all the sunni schools of law ${ }^{60}$ that a mahr is one

51 A wife can insert a clause in the marriage contract ensuring that incompatibility of temperament, refusal of maintenance, unannounced journeys and the taking of another wife without consultation, are provided against, and if any of the conditions is broken, she can approach a lawyer to obtain a divorce in terms of Islamic law.

52 Hammudah Abd al Ati Family Structure in Islam 60-62 (American Trust Publications 1977).

53 In general, gifts given by the husband to the wife during the marriage, are not regarded as satisfaction of the mahr, unless there is proof that that was the intention of both parties at the time (Hodkinson Muslim Family Law. A Sourcebook (1984) 133).

54 It is uncertain whether such a clause will be applicable to third parties. The benefits of such a clause would be that the husband agrees to maintain the wife on dissolution of the marriage, before its inception. It is assumed that this will be done in a "happier" environment, and would thus lead to a more equitable scheme for maintenance for the woman if divorce should occur.

55 Ali The Religion of Islam (1990) 460. For a general discussion see Mansoori Family Law in Islam. Theory and Application (2009) 71; Vahed Islãmic Family Law 29; Western "Islamic 'Purse Strings': The Key to the Amelioration of Women's Legal Rights in the Middle East" 2008 Air Force LR 79 83-88.

56 Mansoori Family Law in Islam 72; Vahed Islãmic Family Law 29; Hodkinson Muslim Family Law 132; Maqsood "Payments To and From the Bride in Islamic Law and Tradition" in Islam for Today (undated) <http://www.islamfortoday.com/ruqaiyyah07.htm> (accessed 2010-1015) 1. The reference by An-Na'im to a "bride price" is therefore incorrect (An-Na'im (ed) Islamic Family Law in a Changing World. A Global Resource Book (2002) 158).

57 A dowry is property brought by the woman for her husband at marriage (Vahed Islãmic Family Law 29).

58 Mansoori Family Law in Islam 73; Ali Muslim Family Law 491; and Maqsood in Islam for Today 2.

59 Qur'an 4:4 and 2:236 respectively; Mansoori Family Law in Islam 71 75; Ali The Religion of Islam 460; and Hodkinson Muslim Family Law 132.

60 Most South African Muslims are members of the Sunni branch of Islam (Mahida History of Muslims in South Africa: A Chronology. South African History Online http://www. 
of the conditions of a valid marriage, and that it is not permitted to forego a mahr. ${ }^{61}$

The aim and purpose of the mahr is disputed. Although earlier Muslim jurists describe a mahr as a price and consideration that a man pays for exclusive rights to sexual and reproductive faculties and analogous to a contract of sale, Mansoori regards this as wrong. This is because the Quran provides for the payment of some of the mahr, even where the marriage is not consummated. ${ }^{62}$ Some scholars regard it as a mark of respect and honour to the wife and an expression of the woman's worth. ${ }^{63}$ As it can give her financial security, ${ }^{6}$ it is regarded as an admission of her independence ${ }^{65}$ and implies an expression of the willingness of the husband to undertake the responsibilities of the marriage, to maintain and protect her ${ }^{66}$ It has been argued that the mahr underlines the prestige and importance of the marriage ${ }^{67}$ However, according to Fournier, there is no consensus amongst Islamic feminists about the nature of mahr. Some regard it as a symbol of female empowerment by a Muslim woman as an independent and consenting party, whist others regard it as the sale of a vagina signed under duress. ${ }^{68}$

Whatever the purpose, Western argues that - regardless of the amount because a woman has the right to receive a mahr as part of the marriage contract, it ensures that a Muslim woman has considerable bargaining power both before and during the marriage. If it is not paid, she may refuse her husband sexual relations until it is paid, or she may divorce him.

The husband (or his family) generally decides on the amount for the mahr and may settle on any sum he deems fit. ${ }^{70}$ The amount would depend on the circumstances of the husband and the position of the wife. ${ }^{71}$ The mahr can be any object of value, such as cash, goods, jewellery, movable and immovable property and shares - as long as it is lawful and capable of possession..$^{2}$ In Hanafi law, a stipulation to perform services is not regarded as a valid dower. ${ }^{73}$ There are certain other prohibitions: a mahr may not be wine or carrion and the granting of a divorce by the husband to an existing

sahistory.org.za/pages/library-resources/online\%20books/history-muslims/1980.htm (accessed 2012-07-24). These are divided into a further four Islamic schools of thought, of which two are important in South Africa. These Sunni schools are the Hanafi (propagated in South Africa mainly by Muslims in Gauteng and KwaZulu-Natal) and the Shafi'i (propagated mainly by Muslims in the Eastern and Western Cape). The other two are Maliki and Hanbali (Alami The Marriage Contract in Islamic Law (1992) 2). This note is limited to the Hanafi and Shafi'i schools of thought.

61 Mansoori Family Law in Islam 71.

62 Mansoori Family Law in Islam 72.

63 Vahed Islãmic Family Law 29.

64 Mansoori Family Law in Islam 72; and Vahed Islãmic Family Law 30.

65 Ali The Religion of Islam 460.

66 Mansoori Family Law in Islam 72; Maqsood in Islam for Today 1.

67 Ibid.

68 Fournier Muslim Marriage in Western Courts. Lost in Transplantation (2010) 13.

69 Western Air Force $L R 85$ - with reference to a "prompt mahr". See discussion hereunder.

70 Mansoori Family Law in Islam 75.

71 Ali The Religion of Islam 461; Maqsood in Islam for Today 1.

72 Vahed Islãmic Family Law 30.

73 Hodkinson Muslim Family Law 132. 
wife, may not be a mahr for another wife. Where the mahr is paid by an invalid object, a "proper mahr" will be payable. ${ }^{74}$

In terms of the Hanafi tradition, the minimum amount is the equivalent of ten dirhams. ${ }^{75}$ Mansoori argues that this amount is an unrealistic consideration, and does not represent a token of love and respect for a wife. ${ }^{76}$ Although no maximum amount is fixed for a mahr, ${ }^{77}$ Vahed argues that it should be set at an amount that the husband can afford to pay. ${ }^{78}$ Ali notes that the mahr is sometimes fixed at a very high and extravagant amount, as a check on the husband's power of divorce. ${ }^{79}$ He regards this practice as foreign to the spirit of the institution of marriage, as laid down in Islam.

If the amount of the mahr is not fixed at the time of the marriage, the validity of the marriage is not affected, as a "proper mahr" has to be paid. ${ }^{80} \mathrm{~A}$ provision in the marriage contract that the wife will not claim a "proper mahr" is seemingly regarded as pro non scripto in the Hanafi school, as the marriage remains valid and a "proper mahr" would be due to the wife. ${ }^{81}$ The effect of the mahr is that the wife becomes the sole owner of the property. ${ }^{82}$

From the discussion above it is clear that there are two possible ways to classify a mahr.

The first classification depends on whether the amount of mahr has been fixed: a "specified mahr" and a "proper mahr". ${ }^{83}$ A "specified mahr" is fixed by the parties at the time of the marriage, or by mutual agreement after the marriage. ${ }^{84}$ The "specified mahr" becomes payable once the marriage is consummated or after valid retirement. ${ }^{85}$ If the amount has not been specified, the amount payable will be a "proper mahr" (mahr mithl) ${ }^{86}$ The "proper mahr" is fixed with reference to the mahr fixed for other female members of similar status and circumstances. This is specifically with reference to the women in the father's family - his sisters and other

74 See discussion in Mansoori Family Law in Islam 74-79.

75 Vahed Islãmic Family Law 30; Hodkinson Muslim Family Law 132. This amounts to less than $£ 5$ (or R60) depending on the exchange rate http://www.muftisays.com/qa/question /608/mehr.html.

76 Mansoori Family Law in Islam 77.

77 Ibid; and Ali The Religion of Islam 462.

78 Vahed Islãmic Family Law 30.

79 Ali The Religion of Islam 462; and Maqsood in Islam for Today 2.

80 Mansoori Family Law in Islam 75-6; Ali The Religion of Islam 460; and Vahed Islãmic Family Law 30.

81 Vahed Islãmic Family Law 30; Mansoori Family Law in Islam 76; and Hodkinson Muslim Family Law 132.

82 Ali The Religion of Islam 460. According to the Qur'an, the mahr is given to the wife as a free gift (4:4) (Ali The Religion of Islam 460).

83 Mansoori Family Law in Islam 77; and Vahed Islãmic Family Law 30.

84 Ibid.

85 Mansoori Family Law in Islam 79. For the similarities and differences in the effect of a valid retirement from a marriage, as opposed to actual consummation of the marriage, see Mansoori Family Law in Islam 81. A full discussion of this is outside the scope of this note.

86 Vahed Islãmic Family Law 30; Mansoori Family Law in Islam 77-78; and Hodkinson Muslim Family Law 133. Ali refers to the "proper mahr" as the "customary dower" (Ali The Religion of Islam 461). 
daughters. ${ }^{87}$ If an adult woman marries herself against a mahr that is less that a "proper mahr", and her guardian objected to it, then a "proper mahr" will be paid. ${ }^{88}$ Similarly, if her guardian allows her to marry for a mahr that is less than a "proper mahr", she can demand a "proper mahr".

The mahr can also be classified by referring to the time of payment: a "prompt mahr" or a "deferred mahr". ${ }^{90}$ Ali notes that some jurists divide the mahr into two equal portions - one portion to be paid at the marriage on demand and the other upon the death of either party. ${ }^{91}$ A "prompt mahr" is paid at the time of the marriage or on demand. ${ }^{92}$ Until the "prompt mahr" is paid, a wife may refuse to live with her husband, and also refuse him sexual intercourse. ${ }^{93} \mathrm{~A}$ "deferred mahr" is payable at the time of dissolution of the marriage, whether through death or divorce. ${ }^{94}$

The mahr is usually settled by payment to the wife directly; or if she is a minor, to her guardian. ${ }^{95}$ She may also accept other property in lieu of her mahr. ${ }^{96}$

There seems to be consensus that the husband may increase the $m a h r^{97}$ voluntarily. Furthermore, a wife may decrease the amount ${ }^{98}$ voluntarily, and may even renounce, waive or relinquish her mahr, partially or in total, in favour of her husband or his heirs. ${ }^{99}$ The waiver will, however, only be effective if she waived it out of her own free will, and without duress. ${ }^{10}$

It should be noted that the mahr can be forfeited in various instances: ${ }^{101}$ one, where the separation is initiated by the wife before consummation of the marriage or valid retirement; two, where the wife waives the mahr to her husband; three, where the wife renounces her mahr as a consideration for her release from the marriage (khul) ${ }^{102}$ four, where the marriage is fasid (invalid) as it was contracted without witnesses and separation took place before consummation; and lastly, where the marriage is nullified on initiation of the wife on the ground that the mahr is less than a "proper mahr", and the nullification takes place before consummation. ${ }^{103}$

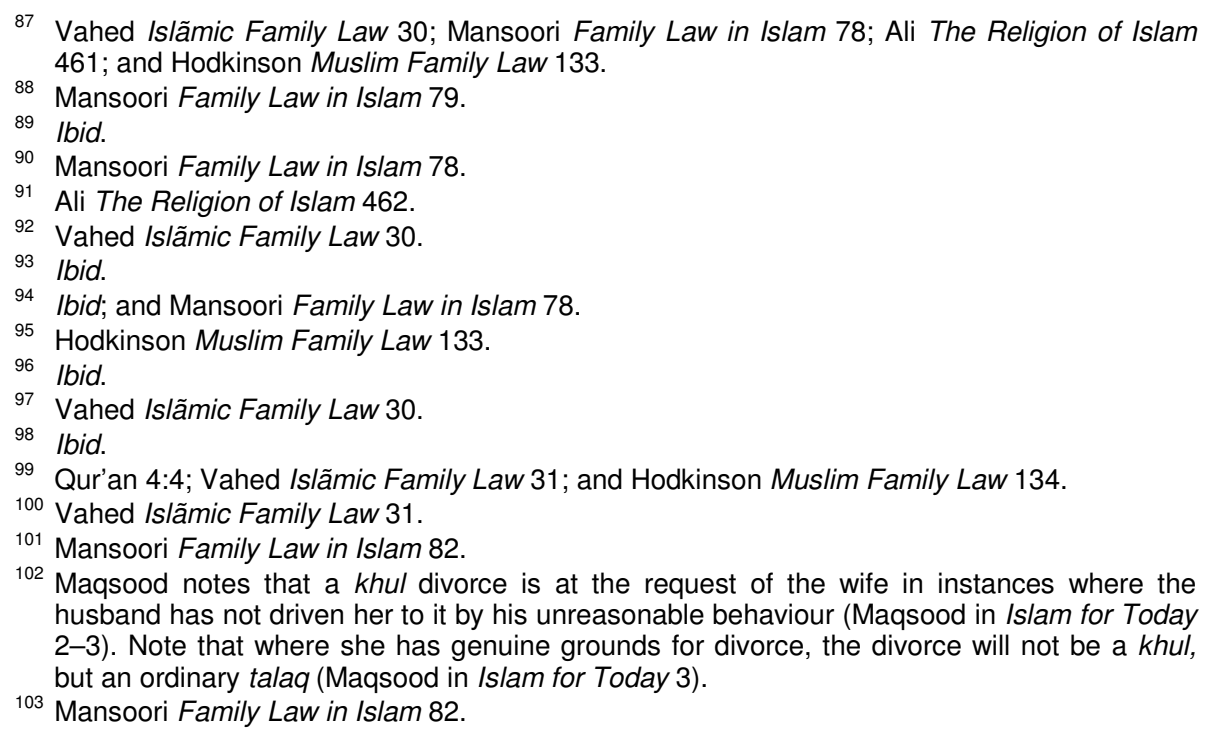


In conclusion, if the mahr is negotiated accordingly, it can be utilized to ensure financial stability for the wife, should the marriage end in divorce.

\section{Duty of spousal support}

There is a duty on the husband to maintain his wife during the marriage. ${ }^{104}$ The duty is not reciprocal. The wife is not obliged to contribute financially to the maintenance of either herself or her husband, and should the husband fail to maintain her, she is entitled to claim arrear maintenance. ${ }^{105}$ An Islamic wife is thus financially in a potentially better position during the marriage, compared to a wife married in terms of the civil law.

Although spousal maintenance is obligatory during the Islamic marriage, it ceases after the Iddah period of (mostly) three months after the divorce. There is seemingly no possibility in Islamic law for extending a maintenance claim for a period longer than the three months, unless it was agreed upon. ${ }^{106}$ It should be noted that during this period, the (ex-) wife cannot be expelled from her place of residence.

\section{Protection at the time of divorce}

A divorce ${ }^{108}$ can take a few forms in Islamic law: ${ }^{109}$ the husband may unilaterally divorce his wife with three Talaqs. ${ }^{110}$ Although it may be more difficult for a wife to initiate a divorce, it is possible through either a Khul or a Faskh. ${ }^{111}$

104 Vahed Islãmic Family Law 31.

105 Vahed Islãmic Family Law 32.

106 Denson and Carnelley "The Awarding of Post-divorce Maintenance to a Muslim Ex-wife and Children in the South African Courts: The Interaction Between Divine and Secular Law" 2009 3 Obiter 679-701. For an opposite view, see Moosa and Karbanee "An Exploration of Mata's [Post Divorce] Maintenance in Anticipation of the Recognition of Muslim Marriages in South Africa: (Re-)Opening a Veritable Pandora's box?" 2004 Law, Democracy and Development 267-288. See in general Quran 2:231; and Quran 2:241.

107 This will constitute a moral and criminal offence (Sura LXV).

108 In the Islamic faith, divorce is seen to be - although allowed - the most hateful thing in the eyes of God (Dawud Hadith 1863; and Majah Hadith 2008). Reconciliation through mediation and counselling by family members, is preferred. Given cultural idiosyncrasies, mediation with a view to reconciliation usually falls to the elders and religious leaders within the community. Where this fails, divorce proceedings can then be initiated by the husband or the wife.

109 See in general Fournier "Flirting with God in Western Secular Courts: Mahr in the West" 2010 International Journal of Law, Policy and the Family 67. Determining the procedure for divorce is dependent upon the timing of and reasons for divorce, the applicable Islamic school of thought (Hanafi, Hanbali, Maliki or Shafi, as different schools of thought can cause some variances in the basic structure), whether he or she is Sunni or Shiite, and the circumstances surrounding the divorce.

${ }^{110}$ For a divorce in Islamic law to be complete and final, the words must be pronounced three times by the husband. Some schools of thought hold that one pronunciation is sufficient if there is no reconciliation during the period of iddah. In such a case, divorce will be final after one such pronunciation. Regardless of this, once the divorce is final, he is obliged to provide his wife with maintenance for the duration of her iddah (Sura II: "Baqara" (verse 229)).

${ }^{111}$ Islam has done much to protect the wife's rights and to save her from having to continue to live in an unhappy environment. Apart from what can be included in the marriage contract (discussed above), she can resort to the courts (qadhi). See discussion below. 
Although there is separation of the estates during the marriage, a wife's property is protected at the time of the divorce, and her property may not be divided. This prevents a husband from taking advantage of her property or wealth through marriage. However, the husband's property may be divided at the time of a divorce, if it is provided for in the marriage contract. ${ }^{112}$

With regard to the mahr, the following is noteworthy. The general rule at the time of divorce is that a husband is not permitted to take back his mahr. ${ }^{113}$ In many cases, the mahr is all that the ex-wife may have to survive on, if her husband divorces her. ${ }^{114}$ However, where the husband divorces his wife before consummation of the marriage, and the amount has been specified, she is only entitled to half the amount of the mahr. ${ }^{115}$ Where the amount has not been specified, she is only entitled to a parting gift. ${ }^{116}$

With a khul divorce, initiated by the wife with the consent of her husband, ${ }^{117}$ a "deferred mahr" may be forfeited. With a faskh divorce, based on fault, the wife can still be entitled to her mahr. ${ }^{118}$ Where a husband transferred his right to divorce to his wife in the marriage contract (tafwīd al talāq), ${ }^{119}$ the contract could set out the conditions under which the mahr is transferred. ${ }^{120}$

Hodkinson notes that theoretically a wife should be able to sue her husband for an unpaid mahr - as an unpaid debt. He highlights that it is unlikely that the wife would sue her husband during the existence of the marriage, and that this would only be feasible at the time of the termination of the marriage. In addition, an unpaid dower would be an unsecured debt, with no priority over other creditors.

${ }^{112}$ Qur'an 2:231.

${ }^{113}$ Mansoori Family Law in Islam 73 - with reference to the Qur'an 2:229 and Qur'an 4:20. Countries, however, differ on this point: An-Na'im notes that in Algeria the ex-wife keeps the mahr upon divorce, but in Egypt she must return it (An-Na'im Islamic Family Law in a Changing World 158).

${ }^{114}$ Leichter The Effect of Islamic Family Law on North American Family Law Issues (2009) 5 $<$ www.iaml.org/iaml_law_journal/back...2/islamic.../index.html> (accessed 2012-06-12).

${ }_{115}$ Qur'an 2:236; Vahed Islãmic Family Law 31; and Mansoori Family Law in Islam 80.

${ }^{116}$ Mansoori Family Law in Islam 72 - with reference to Qur'an 2:236.

${ }^{117}$ Although the wife can seek a divorce from her husband through khul, he still has the prerogative to refuse such a request. In such a case, she can seek dissolution of the marriage through the Islamic courts of law. Siddiqi, former President of the Islamic Society of North America, justifies this notion in that "The Shari'ah has not given the right to a woman to divorce her husband, because only the husband has all the financial obligations of the family. After divorce he will be responsible to provide her maintenance during her 'iddah' and if there are any children in the family then he will be responsible for their expenses. Thus to grant her that right equally with the husband while she has no financial obligation is unfair and unjust." http://islamicislamic.com/divorce.htm\#2._DIVORCE_-CORRECT_ISLAMIC_PRO CEDURE (accessed 2012-07-24). This postulation is questionable, and the authors do not agree with it.

${ }^{118}$ Fournier 2010 International Journal of Law, Policy and the Family Mahr in West 70.

${ }^{119}$ Sūrah al-Ahzāb 33:28.

${ }^{120}$ Omar Islamic Law of Divorce 22; and Mansoori Family Law in Islam 139. Eg, where the husband is guilty of misconduct or malicious desertion, where the husband sues for a divorce in a South African court in terms of the South African law, where the marriage is irretrievably broken down and there is no prospect of reconciliation, or where the husband refuses to maintain his wife or refuses to afford her marital privileges.

${ }^{121}$ Hodkinson Muslim Family Law 134-135. 
As mentioned above, post-divorce maintenance is limited, and Islamic law also does not provide for an equivalent to a redistribution order or an order for forfeiture of benefits, as in the South African civil-law system.

\section{Enforcement}

Where the spouses were married in terms of Islamic law only, the divorce would generally be finalized in terms of Islamic law, and Islamic enforcement procedures would apply. Traditionally, the Imam settles disputes informally, within the community.

There is, however, the possibility of a decision by a qadi (judge). The jurisdiction of the qadi is limited to personal-law matters, and his decision is final. ${ }^{123}$ Moosa notes that in the Western Cape, the Muslim Judicial Council "as a body, assumed the functions of a "collective qadi". ${ }^{24}$ The wife can resort to the qadi if the husband has been incapable or negligent in supplying her with maintenance or has put obstacles in the way of her obtaining it; or if either partner deprives the other of conjugal rights or fails in marital duties. If such is proved, the husband can be compelled to treat her appropriately, to be reconciled, to disburse the proper sums, and to confer her rights upon her in every form. If the husband proves recalcitrant, or refuses to obey the judge's orders, the judge can then compel him to divorce his wife. The wife can also enter a plea in the Islamic court and obtain an injunction if the husband accuses her of lewdness, unchastity or unfaithfulness, or denies his own paternity of her child. If the husband cannot prove his case, the judge will order him to separate himself from his wife, in accordance with the relevant legislation. ${ }^{125}$ The decisions of the qadi are merely binding on the conscience of the parties, and are not final nor enforceable. ${ }^{126}$ It should, however, be noted that, although the terms used in this section give the enforcement procedures an air of formality, in practice these procedures are informal because of the lack of legislative recognition.

With regard to the use of the South African courts for an Islamic divorce, the courts have - to date - refused to grant a divorce to end a religious marriage. ${ }^{127}$ Although the courts have extended civil-law benefits to a religious wife, ${ }^{128}$ it seems unlikely that they would grant a divorce unless

122 Moosa An Analysis of the Human Rights and Gender Consequences of the new South African Constitution and Bill of Rights with regard to the Recognition and Implementation of Muslim Personal Law (1996 PhD Thesis UWC) 321.

123 See Moosa An Analysis of the Human Rights 94. He may consult qualified jurists for their religious opinions (fatwas) (Moosa An Analysis of the Human Rights 95).

${ }^{124}$ Moosa An Analysis of the Human Rights 322.

125 Islam and Divorce - Light of Islam http://home.swipnet.se/islam/articles/divorce.htm (accessed 2012-06-12).

126 Moosa An Analysis of the Human Rights 322.

127 As the Muslim marriage is not regarded as legal, the courts do not have jurisdiction to set it aside. The courts will grant a divorce in dual marriages, where the parties were married in terms of both civil law and a religion. The divorce, however, only sets the civil marriage aside, and not the religious marriage (Amar v Amar 1999 (3) SA 604 (W)).

${ }^{128}$ In Daniels v Campbell 2004 (5) SA 331 (CC); Hassam v Jacobs 2009 (5) SA 572 (CC), the Constitutional Court extended the rights of a civil widow in terms of the Intestate Succession Act 81 of 1987, and the Maintenance of Surviving Spouses Act 27 of 1990 - to Muslim 
provision is specifically made therefore in legislation. ${ }^{129}$ However, the South African courts have enforced rights and duties created by a religious marriage, where such rights and duties are not in dispute. In Ryland v Edros, the court held that, as there was no dispute as to the applicable religious doctrine, and as the obligation was clear under religious law, it could enforce the contractual (financial) obligations. ${ }^{130}$ In this matter, the court ordered that the plaintiff was liable in respect of arrear maintenance for the marital period as well as a consolatory gift, as the divorce was at the unjustified behest of the plaintiff. The court specifically ordered that the wife was not entitled to an equitable share of her tangible and intangible contributions to the growth of her husband's estate. ${ }^{13}$

It is submitted that in light of Ryland, and if the mahr clause is Shariahcompliant, there is no prima facie reason why the South African courts should not be able to enforce payment of the mahr, even if it could not grant a divorce. ${ }^{132}$

\section{Conclusion}

Where the parties are married in terms of Islamic law only, the dissolution thereof will occur in terms of Islamic law. There is no option of automatic asset-sharing at the time of the divorce, unless the parties agreed thereto in the Muslim marriage contract. This position is particularly prejudicial to a wife. In an attempt to prevent prejudice, the Muslim marriage contact and the mahr are essential to protect the wife financially at the time of divorce.

During the marriage, the duty is on the husband to maintain his wife, but as post-divorce maintenance is limited, the only claims the wife may have are for specific donations, if any, made in the Muslim-Marriage contract and/or an unpaid mahr.

It would be particularly financially helpful for a wife who gave up her career for her family, if, as suggested by AMAL, the mahr is stipulated in money and subject to an inflationary increase at the time of payment, and if she donated certain assets and/or a share in the annual profits in the husband's business. ${ }^{133}$

widows. These rights granted more to the Muslim wife than she would have been entitled to in terms of Islamic law.

${ }^{129}$ Clause 9 of the Muslim Marriages Bill of 2010, makes provision for the relevant court to terminate an Islamic marriage.

1301997 (2) SA 690 (C) 718I-719A.

$131719 \mathrm{~A}$.

132 The South African courts are hesitant to interfere in religious issues. In Taylor $v$ Kurtstag 20057 BCLR 705 (W), the court refused to prevent the shunning of a Jewish man who acted in contravention of his religious duties in light of the constitutional freedoms of association and religion (ss 31 and 18 of the Constitution). (See discussion by Barrie "Judicial Review and Religious Freedom in South Africa" 20052 TSAR 162). Any limitation of the rights of the applicant was found to be reasonable and justifiable in terms of section 36 of the Constitution. It is important to note that the decision of the Beth Din was not questioned, and the court was not approached to enforce the decision.

${ }^{133}$ This suggestion is in line with the AMAL suggestion (see fn 47 above). 
With regard to the enforcement of any agreement, the lack of legislative recognition of Muslim marriages remains a stumbling block towards adequate enforcement of rights.

\section{DUAL MARRIAGES}

\section{South Africa}

It is evident from the discussion, that the two legal systems are vastly and fundamentally different. The structure during, and at the time of divorce, as well as the enforcement structures, is dissimilar.

These differences are especially problematic to those couples who marry each other twice - once in terms of Islamic law and once in terms of civil law. In South Africa, Muslim couples often attempt to bring the two sets of rules together, by including Islamic rules in a civil-law antenuptial contract. ${ }^{134}$ However, the consequences at the time of divorce would depend on the institution granting the divorce.

Islamic courts will uphold the principles applicable to the mahr, as well as the terms of a Muslim marriage contract as included and agreed to by the parties. ${ }^{135}$

The South African law only recognizes the civil marriage as legal, and not the Islamic marriage. Where the divorcing couple cannot reach a settlement agreement, the courts will apply the civil-law rules to the exclusion of the Islamic-law principles. ${ }^{136}$ The terms in the antenuptial contact will be interpreted through the lens of the civil-law rules; and although these contractual terms will be considered, it is not, as discussed above, the only guiding principle. The court may make orders for post-divorce maintenance, forfeiture of benefits, or for redistribution, should any or all be applicable. In addition, the court would ignore the principles applicable to the mahr, that are not specifically included in the Muslim marriage contract.

\section{Canadian caveat}

The consequences of the attempt to include the mahr in a Muslim marriage contract preceding a Western marriage, are not limited to South Africa. In Canada, the enforcement of these contracts is problematic and has lead to a variety of outcomes in the Canadian courts. Fournier argues that, where the mahr is included in a Muslim marriage civil law contract, it is transplanting into the national law and cannot be undone - as the contract immediately becomes rooted in the country's legal, historical, political and social backgrounds:

\footnotetext{
${ }^{134}$ As an example, the practical application of the mahr in KwaZulu-Natal, where the spouses are married in terms of both civil and Islamic law, serves as an example.

${ }^{135}$ Leichter The effect of Islamic family law on North American family law issues (2009) 6 $<$ www.iaml.org/iaml_law_journal/back...2/islamic.../index.html> (accessed 2012-06-12).

${ }^{136}$ See in general Manjoo The Recognition of Muslim Personal Laws in South Africa: Implementation for Women's Human Rights. Project Report.
} 
"Now being dynamically situated elsewhere, it becomes a hybrid and transformed version of what was once described as mahr by classical Islamic jurists."

Fournier shows that the manner in which the mahr is dealt with by the Canadian courts can take three very different forms: ${ }^{138}$

In the first approach, the Islamic law is regarded from a legal-pluralism perspective, although this approach does not lead to a uniform outcome. The mahr is regarded as an expression of religious identity, and the imam is an expert witness in the court. In some courts, the mahr is recognized as a manifestation of identity, and enforceable as an Islamic custom. ${ }^{139}$ In Nathoo $v$ Nathoo and in $M(N M) v M(N S)$, the mahr was regarded as a "marriage agreement" in addition to the usual reapportionment of assets resulting in the wife gaining more than she would have had in terms of the fairness principle, and in terms of the applicable Family Relations Act. ${ }^{140}$

Fournier notes that in the Quebec courts, the mahr is not recognized and is regarded as unenforceable in instances of a khul divorce where the wife initiated the divorce. ${ }^{141}$ Furthermore, in Ontario, the mahr is regarded as too "foreign to be adjudicated by a Western non-Muslim judge". ${ }^{142}$

The second approach Fournier describes is the formal equality approach. ${ }^{143}$ In this instance, the mahr as an enforceable contractual issue on the basis of the marriage agreement. ${ }^{144}$

The third approach is one of substantial equality, where the mahr is viewed under the umbrella of Western family law, and "the judge engages in sexual identity politics: gendered understanding of mahr." Canadian courts differ in the application of this principle. In Quebec, in MHD $\checkmark E A$, the court argued that the mahr is a "religious custom ... [that] has an effect on substantive equality", making it enforceable in light of the rules of equity, and found that the mahr as due even though the wife initiated the divorce. ${ }^{146}$ On the other hand, in another Quebec court, MF $v M A A$, the court regarded the mahr as unenforceable on the basis of equity. ${ }^{147}$ This outcome also occurred in the Nova Scotia court in Vladi $v$ Vladi ${ }^{148}$, where the

${ }^{137}$ Fournier Muslim Marriage in Western Courts. Lost in Transplantation 2.

${ }^{138}$ Fournier 2010 International Journal of Law, Policy and the Family 70.

139 British Columbia cases: Nathoo v Nathoo [1996] BCJ 2720 (SC), and M (NM) v M (NS) 2004 BCSC 346,26 BCLR (4th) 90.

${ }^{140}$ Fournier argues that the court was incorrect in their decision (Fournier Muslim Marriage in Western Courts. Lost in Transplantation 67-68). The court followed Nathoo.

${ }^{141}$ Fournier with reference to MHD v EA (QCA) unreported case number 500-09-001296-896 dated 23 September 1991, and I (S) V $E$ (E) (CSQ) unreported case number EYB 200595189 (Fournier Muslim Marriage in Western Courts. Lost in Transplantation 68-69).

142 Fournier Muslim Marriage in Western Courts. Lost in Transplantation 72-76, with reference to Kaddoura $v$ Hammoud (1998) 44 RFL $\left(4^{\text {th }}\right) 228$, 168 DLR $\left(4^{\text {th }}\right) 503$ (OntGD).

${ }^{143}$ Fournier 2010 International Journal of Law, Policy and the Family 71.

144 Amlani v Hirani 2000 BCSC 1653, 194 DLR $\left(4^{\text {th }}\right) 543$.

${ }^{145}$ Fournier 2010 International Journal of Law, Policy and the Family 71-72.

${ }^{146}$ Fournier Muslim Marriage in Western Courts. Lost in Transplantation 94, with reference to MHD v EA (QCA) unreported case number 500-09-001296-896 dated 23 September 1991.

${ }^{147}$ Fournier Muslim Marriage in Western Courts. Lost in Transplantation 95, with reference to MF $v$ MA A (CSQ) unreported case number 500-12-253264-009 dated 11 March 2002.

148 (1987) 7 RFL (3d) 337, 39 DLR $\left(4^{\text {th }}\right) 563$ (NSSC-TD). 
court refused to enforce the mahr (as part of the Iranian matrimonial law), on the basis that the law was considered archaic and repugnant to the ideas of substantial justice in the province. ${ }^{149}$

\section{Conclusion}

The divergent judgments in the Canadian courts are unfortunate, and for a Muslim wife in Canada there is no legal certainty. This is also the case in South Africa. If there is no agreement between the parties at the time of the divorce, and a South African court is approached for enforcement, the court is unlikely to interfere and will not enforce Islamic principles not contained in an agreement.

As discussed above, if it is a dual marriage, the court will - rightly or wrongly - merely apply the civil-law principles to the exclusion of the Islamiclaw principles.

If it is an Islamic divorce (only), the court would only enforce any contractual arrangements. It would also, with reference to Ryland $v$ Edros, enforce that which is due if there is agreement between the parties on what is liable in terms of Islamic-law principles.

The South African courts will only decide on religious principles if provision is made through legislative intervention. The Islamic spouses are in these instances limited to Islamic-enforcement procedures.

\section{CONCLUSION}

The co-existence of and interaction between the two marriage systems in South Africa, have given rise to much uncertainty and debate. The debate has grown as the South African courts granted Islamic wives certain civil-law rights, and with the drafting of the two Muslim Marriages Bills. However, the adoption of legislative certainty has yet again stalled, making a legislative solution to the problems unlikely.

The aim of this article was to compare the financial structures of the two marriage systems during the marriage and at the time of the divorce, with specific reference to the matrimonial property systems, marital agreements, and the discretion of the marriage-terminating authority (the courts in the South African legal system and the qadi in the Islamic system). Underlying the discussion was the impact of the various systems on the financial protection of wives at the time of divorce - on those who give up their income-generating careers to care for their families.

During the marriage, an Islamic wife is in a better position than a civil-law wife, as the duty to maintain falls on the husband only, and is not reciprocal as in civil marriages. At the time of divorce, the protection measures are less rosy for Islamic wives.

In terms of South African civil law, the protective measures are generally adequate, as there is an automatic sharing of assets at the time of divorce, except where the marriage was entered into out of community of property

${ }^{149}$ Fournier Muslim Marriage in Western Courts. Lost in Transplantation 95. 
without the accrual after 1984/1988. However, at the time of the divorce, the court still has discretion to award permanent maintenance in certain circumstances. The most vulnerable group is in practice the smallest group of marriages/divorces.

With Islamic marriages, the estates of the spouses are separate, without an automatic sharing at the time of divorce. The financial protection of an Islamic wife, if there is no agreement, is thus dependent on the provisions of the premarital agreement and the concept of the mahr. Enforcement hereof falls within the realm of the Islamic-law procedures, and the South African courts will only enforce where there is agreement about the religious principles. The courts will not interpret or pronounce on religious principles.

In instances of dual marriages where the mahr is included in a Muslim marriage agreement, it could potentially enable a more equitable financial division at the time of divorce. However, once included in a civil-law document, the mahr will lose its unique Islamic-law character, and will be interpreted through the lens of the civil law - similar to the Canadian situation. The mahr would be enforced by the South African courts as a contractual provision, without having regard to the additional Islamic-law principles that form an integral part of the concept.

Whatever marital system is chosen, a soon-to-be-wife has to ensure that she protects herself financially at the time of divorce, especially if she is planning to have children, and in the process accepts a lesser career or no career at all. Without proactive negotiations at the beginning, financial security at the time of divorce may in fact be wishful thinking. 